\title{
Rostros de la demencia: testimonio familiar de la Fundación Alzheimer de Nicaragua (FADEN)
}

\author{
Dr. Armando Ulloa González \\ Vice Decano \\ Facultad de Ciencias Médicas \\ UNAN-Managua
}

Tengo que felicitar a la Fundación Alzheimer de Nicaragua (FADEN) por su reciente publicación. Ésta describe las experiencias vividas por los familiares de pacientes afectados por esta enfermedad. Como lo expresan los mismos familiares, el propósito del libro es "compartir [el] testimonio y mostrar cuánta riqueza tenemos como seres humanos".

Este libro recoge las experiencias personales y familiares de los principales miembros del núcleo familiar de una paciente con Alzheimer. Sobre todo, relata los diversos momentos de la vida de la paciente, y la alegría, tristeza e incomprensión que experimenta cada uno de sus familiares al enfrentar una enfermedad desconocida por todos. Describe la lucha por no perder de vista la esperanza en la vida y a la vez sortear la incertidumbre de no poder distinguir los hechos

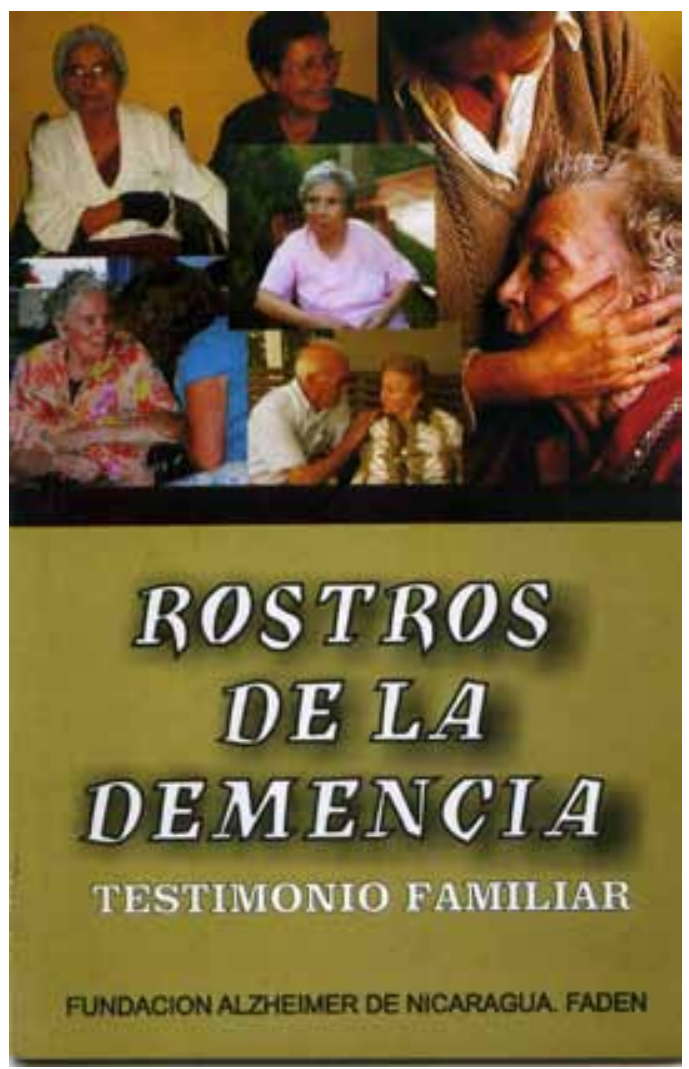
acontecidos que se pierden en los límites inexistentes de la realidad y los recuerdos.

Los testimonios narrados van describiendo el desarrollo natural de la evolución de esta enfermedad, en la cual existen diversas etapas caracterizadas por diversos síntomas y manifestaciones clínicas, la relación médico-paciente, familia y comunidad. Pero a la vez describe las situaciones difíciles que se presentan en el entorno familiar y las contingencias necesarias que tuvo que agenciar la familia, 
no perdiendo de vista los principios y valores para darle una buena atención a la paciente.

Este libro aporta y contribuye a interpretar de forma adecuada y pertinente los fenómenos que dan cuenta de la enfermedad de Alzheimer, una realidad tangible en nuestro país, brindando información necesaria y útil para la sociedad nicaragüense y en particular para las familias que tienen algún ser querido con este mal. La información brindada puede contribuir a generar una mayor comprensión y esperanza para brindar una mejor atención con cualidades humanas y valores éticos.

Los diversos testimonios ejemplifican que al brindar una atención con respeto ético, lleno de afecto y amor, en unidad familiar, es posible lograr de manera exitosa una buena comunicación entre el paciente, sus familiares y el personal médico, superando los temores y conflictos existencialistas y sentimientos de impotencia que se experimentan a lo largo de los cuidados brindados por los familiares.

Asimismo, la obra permite dar cuenta de estas situaciones a las diversas instituciones formativas y de prestación de servicios de salud que aún no han visibilizado estas temáticas, donde están en juego el respeto y la promoción de derechos, la equidad en los cuidados de atención, el respeto de la autonomía del paciente, y la necesidad de darle un rostro real y humano con calidad de vida. 